\title{
Propuestas de los estudiantes para evitar el plagio académico
}

\section{Student proposals to prevent academic plagiarism}

Violeta Cebrián-Robles. Universidad de Vigo. violetacbr@uvigo.es

Manuela Raposo-Rivas. Universidad de Vigo. mraposo@uvigo.es

Francisco José Ruiz Rey. Universidad de Málaga. pacoruizster@gmail.com

Manuel Cebrián De La Serna. Universidad de Málaga. mcebrian@uma.es

\section{RESUMEN.}

La transformación digital de la producción de trabajos en el mundo universitario nos ofrece muchas ventajas como también obligadas precauciones en las instituciones para evitar las prácticas deshonestas. Hay muchos estudios en la literatura sobre el plagio académico pero en pocas ocasiones se le pregunta a los más interesados por la solución, como es a los propios estudiantes, quienes en su inmensa mayoría consiguen sus títulos con esfuerzo y a quienes más perjudican estas malas prácticas. El diseño de la investigación fue no experimental de tipo transversal con un cuestionario y fiabilidad de Alfa de Cronbach 0,775, obteniendo datos de 823 estudiantes de 10 instituciones y 3 países Iberoamericanos diferentes sobre las soluciones que ven ellos más eficaces, su conocimiento por las medidas preventivas de sus instituciones y cómo de competente se ven ellos a nivel individual para evitarlo. Las principales soluciones de los estudiantes consisten en tres tipos, uno primero formativo preventivo, un segundo punitivo y un tercero totalmente laxo. No existiendo diferencias por países, salvo que muestran mayor autopercepción en cuanto a competencia para enfrentarse al plagio en los cursos superiores.

\section{PALABRAS CLAVE.}

Plagio, ética, integridad, formación de profesores, competencias.

\section{ABSTRACT.}

The digital transformation of the production of works in the university world offers us many advantages as well as obligatory precautions in the institutions to avoid dishonest practices. There are many studies in the literature on academic plagiarism, but on few occasions those most interested in the solution are asked, such as the students themselves, the vast majority

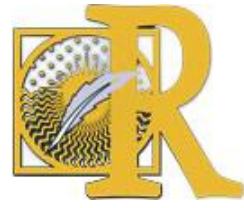


of whom obtain their degrees through hard work and who are most affected by these bad practices. The research design was non-experimental, cross-sectional with a questionnaire and a reliability of Cronbach's Alpha 0.775, obtaining data from 823 students from 10 institutions and 3 different Iberoamericans countries on the solutions they consider most effective, their knowledge of the preventive measures of their institutions and how competent they consider themselves at an individual level to avoid them. The students' main solutions consist of three types, the first being formative and preventive, the second punitive and the third totally lax. There are no differences by country, except that they show greater selfperception in terms of competence to deal with plagiarism in higher grades.

\section{KEY WORDS.}

Plagiarism, ethics, integrity, teacher training, competency.

\section{Introduction.}

Similar to many aspects of technological changes, the advantages of the digitization of the production of work by students in universities come along with certain problems such as dishonest practices, among which we find plagiarism in academic work (Cebrián-Robles, et.al., 2016). Circumstances that place us with an ethical problem in digital competence that goes beyond technical skills. This has motivated their attention because of the importance of the issue, and collected in the sections of recommendations for the promotion of digital competences of DigComp citizens, specifically in competence 3, Content creation and subsection 3.3 Copyright and licenses (Carretero, et.al., 2018, p.11) and the same report referring to DigCompEdu teachers (Redecker, 2017), where we find recent studies regarding the competencies of university teachers (Cabero-Almenara, et. al., 2021) and students of education degrees or future teachers (Gallego-Arrufat, et. al., 2019). In the DigCompEdu report we can read in competence 6 the need for teachers to favor the "development of students' digital competence", promoting their active participation through ICT, a task that should be considered together and especially in what summons us in this article on dishonest practices and plagiarism, and which is collected in the subsection within this competence 6 , in point 6.3. on the creation of content at $\mathrm{C} 1$ level. Leader in teachers, they have to be competent in the "Comprehensive and critical promotion of digital content creation by students". Redecker, 2017, p.83) and "detecting and avoiding plagiarism, e.g. by using digital technologies".

In the specialized literature we find interesting works on students' attitudes towards plagiarism that compile experiences in different countries (Bretag, 2016; Amiri, \& Razmjoo, 2016; Cebrián-Robles, et. al., 2018), to a lesser extent we find comparing different countries and contexts (Ehrich, et. al., 2014). Studies of which are the best proposals for their solution have been raised, from a broad perspective of dimensions to be improved (Zrnec \& Lavbič, 2017), especially their pedagogical proposals (Kaktinš, 2018), to more comprehensive and artificial intelligence-based proposals (Gasparyan, et.al., 2017. Students have been asked about their understanding of institutional regulations regarding plagiarism and dishonest practices (Adam, et. al., 2017), but have not been asked about the solutions they would recommend. Undoubtedly, the full complexity of the problem needs to be addressed from all dimensions

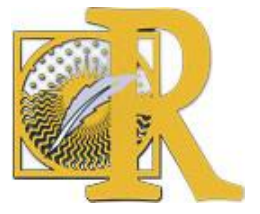


(Sureda-Negre, et.al., 2019), otherwise we will not be able to propose effective solutions, and in this holistic view it is also appropriate to ask the protagonists.

No one argues in this literature that to encourage this commitment, teachers and institutions should inform students of these mechanisms and technologies for the detection of plagiarism; as well as generate a positive culture, while developing training plans and debates on the creation of content supported by ethical values and educational quality, such as clearly defining and disseminating the sanctions in case of plagiarism (López-Puga, 2014; Walker \& White, 2014; Sureda-Negre, et.al., 2019). For this reason, and before promoting this type of training and promotion actions in students, it would be interesting to know what knowledge they have about these norms and values; at the same time, it would be interesting to know what proposals they put forward to avoid these dishonest practices. In this way we establish a debate between the knowledge they have and the analysis of their proposals, so that we can become more aware of the problem and seek agreements and regulations agreed upon by all members of the institution, including and especially the students themselves. But we have not asked what they think about it and what kind of measures we could propose to avoid this plagiarism. We did not find many references to this in the specialized literature, but we did find recommendations on the need to involve students in all university phases, as we have already seen in the DigCompEdu report.

Institutions are increasingly taking initiatives from different angles, such as the creation of standards and ethical codes, such as the use of anti-plagiarism tools. Since most of the initiatives are aimed at students, we should find out what they think about these solutions and make them aware of them. Likewise, we should ask them what they and the institution itself are competent to do to avoid these practices. There is not much research that directly asks students about the solutions they consider most effective; after all, they are among the most harmed and interested that these practices do not occur by a minority of students who seek these unethical shortcuts.

\section{Method.}

According to Hernández, et. al. (2014), the research was carried out with a non-experimental cross-sectional design. It is part of a broader $\mathrm{R}+\mathrm{D}+\mathrm{i}$ research project on the evaluation of competencies in external practices in undergraduate and postgraduate degrees in Education. The choice of the study sample is by convenience according to the proximity and accessibility of the informants, as they belong to the ten universities collaborating in this $R+D+i$ research project. The sample consisted of 823 students from universities in three different countries as shown in Table 1.

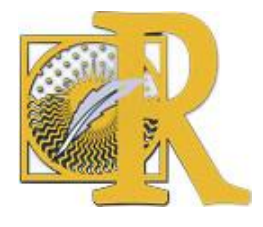

Fecha de recepción: 20-08-2021 Fecha de aceptación: 27-08-2021 
Table 1. Ages by country.

\begin{tabular}{|l|c|c|c|c|}
\hline Countries & Between 18-20 years old & Between 21-24 years old & 25 and over & Totals \\
\hline España & 149 & 275 & 115 & 539 \\
\hline Portugal & 27 & 82 & 23 & 132 \\
\hline Colombia & 3 & 10 & 139 & 152 \\
\hline Totals & 179 & 367 & 277 & 823 \\
\hline
\end{tabular}

\subsection{Objective.}

To analyze the knowledge that students have about measures to prevent plagiarism in their institutions, as the solution they propose for it and their competence to deal with these dishonest practices.

\subsection{Research questions.}

This objective will be achieved by answering three questions posed to students: are they aware of their institution's measures to prevent plagiarism?; what solutions can be most effective in preventing plagiarism?; and, how competent do they feel individually to prevent plagiarism?

\subsection{Instrument.}

The instrument used was developed from other instruments already existing in the scientific literature on the subject (Comas-Forgas \& Sureda-Negre, 2010; Sureda-Negre, et al., 2015; Ehrich et al., 2014). After its validation through pilot application and expert consultation, it was subjected to translation and semantic adaptation attending to the countries of the study to produce an electronic version. The Cronbach's alpha of the total questionnaire is 0.775.

From this instrument for this study we used a three-block structure: block I. institutional contextualization data (university, degree and course), block II personal (gender, age), and block III. Do you know if there are ICT tools at your university to avoid plagiarism? Do you know if there is guidance at your university to avoid plagiarism? Do you know if there is guidance at your university to avoid plagiarism? And, do you know if there is guidance at your university to avoid plagiarism? In the case that the student has plagiarized, what measures are taken? What solutions do you consider most effective to avoid plagiarism? Do you consider that you have the knowledge and skills to avoid plagiarism? Do you consider that you have the knowledge and skills to avoid plagiarism? Do you consider that you have the knowledge and skills to avoid plagiarism?

The following are the questions posed in the questionnaire and the items as possible answers: 
Do you know if there are ICT tools at your university to prevent plagiarism? Yes, No Don't Know/No Contest

There is an institutional platform.

Specific software.

Not available.

Other, please indicate which one:

Do you know if there is guidance at your university to avoid plagiarism? Yes, No Don't Know/No Contest

The professors provide the necessary information.

There is information on the faculty website.

There is information in the library.

There is material in the virtual campus or virtual platform of the courses.

There are courses and seminars.

Others, indicate which:

In case the student has plagiarized, what measures are taken? Yes, No Don't Know/No Contest

It is not contemplated in the regulations, there is no protocol.

Must redo the assignment.

The student fails and has to repeat the course.

Repeat the course.

Each teacher acts differently.

Other, indicate which:

What solutions do you consider most effective in preventing plagiarism?

1] Strongly Disagree [2] Disagree [3] Neutral [4] Agree [5] Strongly Agree

1.Training on copyright and how to prevent plagiarism.

2. Plagiarism detection software.

3. If someone is identified as plagiarizing, the subject is repeated.

4. Create a code of ethics among all members of the University.

5. More monitoring and support from the faculty during the assignment.

6. Better coordination between subjects in terms of the weight or occupation in time of the tasks.

7. If someone is identified as plagiarizing, expel him/her from the university.

8. Positive actions such as recognizing "best student of the month".

9. Have sources of information available to explain and help prevent.

10. If someone is caught plagiarizing, have them repeat the assignment.

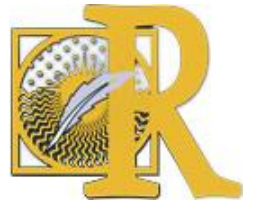


11. Counseling for consultation at any time and place.

12. Clear and specific regulations for each case.

13. No measures, since in education plagiarism can be considered as learning from others by imitation.

14. Other, please indicate which:

\section{Do you consider that you have the knowledge and skills to avoid plagiarism? Evaluate between 0 (Not at all) to 10 (Very competent)}

\subsection{Data analysis.}

For the reliability analysis, Cronbach's alpha coefficient is proposed, in order to know to what extent, the analyzed items are measuring the same thing. The analysis was carried out in the SPSS version 21.0 statistical software, for the four proposed questions and with data from a sample of 823 individuals (from three different countries; Spain (539), Colombia (152) and Portugal (132). With respect to internal consistency, the following "Cronbach's alpha" was obtained with a value of 0.775 (considered an adequate value) for the 13 items related to the possible effective solutions to avoid plagiarism.

The fundamental purpose of construct validity is to validate the theory underlying the assessment or measurement system. Evidence of construct validity is obtained through factor analysis. This method groups items according to their correlations, indicating how many dimensions make up a variable and which items make up each dimension. The items that make up a dimension have high correlations with each other, grouping these items as a factor. The items that do not belong to a dimension mean that they are isolated and do not measure the same as the other items, therefore they should be eliminated. The following analyses will be performed: determination of the correlation matrix, KMO index (KaiserMeter-Olkin) or sample adequacy measure and Barlett's test of sphericity.

\section{KMO (Kaiser-Meter-Olkin) sampling adequacy measure for the different questionnaires, Barlett's sphericity and factor analysis.}

The KMO (Kaiser-Meter-Olkin) sampling adequacy measure in the different questionnaires Barlett's sphericity and factor analysis - allows comparing the magnitude of the observed correlation coefficients with the magnitude of the partial correlation coefficients. The KMO statistic varies between 0 and 1 . Small values indicate that factor analysis may not be a good idea, since correlations between pairs of variables cannot be explained by other variables. Obtaining low values in the $\mathrm{KMO}$ index, between 0.5 and 0 is not advisable to continue with factor analysis. The KMO value is 0.832 , which means that our matrix is adequate to continue with the factor analysis.

The dimensions are formed when the questions of the questionnaire are analyzed. In this research 13 items were analyzed. The confirmatory factor analysis indicates that there are 3 factors with a cumulative variance of $53.862 \%$.

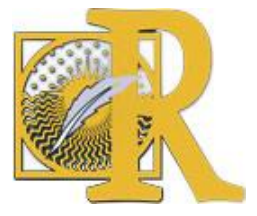

Fecha de recepción: 20-08-2021 Fecha de aceptación: 27-08-2021 
Factor 1: Proactive response.

Factor 2: Punitive response.

Factor 3: Lax response.

\section{Rotated Component Matrix.}

Using the Varimax method, we obtain the rotated components matrix that will help us to see which variables can be considered in the different factors, as well as which variables we could discard for subsequent studies (we could do without items with values lower than 0.5 in the set of all the components). The information is shown in Table 2 below:

Table 2. Rotated component matrix.

\begin{tabular}{|l|c|c|c|}
\hline \multicolumn{1}{|c|}{ Items responses } & \multicolumn{2}{c|}{ Components } \\
\cline { 2 - 4 } & 1 & 2 &,- 026 \\
\hline Training on copyright and how to prevent plagiarism. &, 630 &, 224 &,- 113 \\
\hline Plagiarism detection software. &, 304 &, 658 &, 142 \\
\hline If someone is caught plagiarizing, the subject is repeated. &,- 010 &, 827 &, 067 \\
\hline $\begin{array}{l}\text { Create a code of ethics among all members of the } \\
\text { University. }\end{array}$ &, 511 &, 441 &, 004 \\
\hline $\begin{array}{l}\text { More monitoring and support from faculty during the } \\
\text { assignment. }\end{array}$ &, 687 &, 084 &, 048 \\
\hline $\begin{array}{l}\text { Better coordination between subjects in terms of the } \\
\text { weight or time occupation of the assignments. }\end{array}$ &, 675 &, 008 &, 476 \\
\hline $\begin{array}{l}\text { If someone is caught plagiarizing, expel him/her from the } \\
\text { university. }\end{array}$ &,- 099 &, 650 &, 777 \\
\hline $\begin{array}{l}\text { Positive actions such as recognizing "best student of the } \\
\text { month". }\end{array}$ &, 269 &, 245 &, 622 \\
\hline Have sources of information that explain and help prevent. &, 755 &, 119 &, 073 \\
\hline $\begin{array}{l}\text { If someone is caught plagiarizing, repeat the task. } \\
\text { An advisory service for consultation at any time and place. }\end{array}$ &, 270 &, 560 &,- 183 \\
\hline Clear and specific regulations for each case. &, 719 &, 077 &, 123 \\
\hline $\begin{array}{l}\text { No measures, because in education plagiarism can be } \\
\text { considered as learning from others by imitation. }\end{array}$ &,- 046 &,- 169 &,- 061 \\
\hline
\end{tabular}


The results of the three factors are confirmed in the following items that can be synthesized as groups proposing three different measures:

Factor 1: Items 1, 4, 5, 6, 9, 11 and 12. Proactive response. Where the answers are oriented to training and prevention, creating clear regulations and a code of ethics, with more followup and teaching support to students through homework, coordination between subjects with time and weight according to each case. Creating sources or spaces of information that explain and help to prevent, with advice and consultations at any time and place.

Factor 2: Items 2, 3, 7 and 10. Punitive response. Among which are the use of anti-plagiarism tools, with sanctions such as repeating the subject, repeating the assignment and expulsion from the university.

Factor 3: Items 8 and 13. Lax response. They are oriented to highlight the best student of the month and do not take any action because learning is imitation of others.

\section{Comparison of means and by sex.}

Here we will compare the data according to sex, using an analysis of equality of means based on the Student's t-test for two independent samples. We will accept that the means are significantly different in the different items when the significance value is less than 0.05 . (Female 1; Male 2). In total there are 603 women and 220 men. An analysis of the means in Table 3 shows that the means of the women are lower in a significant percentage of the items; although, in general, the differences are not very significant.

Table 3. Responses to proposals according to sex and means.

\begin{tabular}{|l|c|c|}
\hline \multicolumn{1}{|c|}{ Items responses } & $\begin{array}{c}\text { Woman 1 } \\
\text { Man 2 }\end{array}$ & Average \\
\hline Training on copyright and how to prevent plagiarism. & 1,00 & 4,22 \\
\cline { 2 - 3 } & 2,00 & 4,10 \\
\hline Plagiarism detection software. & 1,00 & 3,88 \\
\cline { 2 - 3 } & 2,00 & 3,91 \\
\hline If someone is caught plagiarizing, the subject is repeated. & 1,00 & 2,86 \\
\hline Create a code of ethics among all members of the University. & 2,00 & 3,06 \\
\hline More follow-up and support from the faculty during the assignment. & 1,00 & 3,74 \\
\cline { 2 - 3 } & 2,00 & 3,84 \\
\hline $\begin{array}{l}\text { Better coordination between subjects in terms of the weight or occupation in } \\
\text { time of the tasks. }\end{array}$ & 1,00 & 4,22 \\
\cline { 2 - 3 } & 2,00 & 4,19 \\
\hline
\end{tabular}




\section{INTERNATIONAL JOURNAL OF EDUCATIONAL \\ RESEARCH AND INNOVATION \\ REVISTA INTERNACIONAL DE INVESTIGACIÓN EINNOVACIÓN EDUCATIVA}

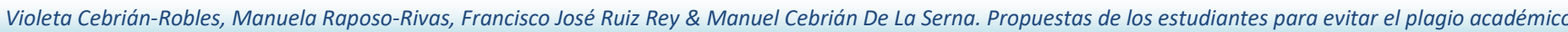

\begin{tabular}{|l|c|c|}
\hline If someone is caught plagiarizing, expel them from the university. & 1,00 & 1,65 \\
\cline { 2 - 3 } & 2,00 & 1,99 \\
\hline Positive actions such as recognizing "best student of the month". & 1,00 & 2,68 \\
\cline { 2 - 3 } & 2,00 & 3,09 \\
\hline Have sources of information available to explain and help prevent. & 1,00 & 4,17 \\
\hline If someone is caught plagiarizing, they can repeat the task. & 2,00 & 4,10 \\
\hline An advisor for consultation at any time and place. & 1,00 & 4,01 \\
\cline { 2 - 3 } & 2,00 & 4,16 \\
\hline Clear and specific regulations for each case. & 1,00 & 4,12 \\
\hline & 2,00 & 4,06 \\
\hline No measures, because in education plagiarism can be considered as & 1,00 & 4,33 \\
\hline learning from others by imitation. & 2,00 & 2,29 \\
\hline
\end{tabular}

\section{Comparison of averages by country of consideration of knowledge and skills to avoid plagiarism.}

In this section we are going to analyze, in view of the data obtained, as shown in Table 4, whether the means of the groups formed by the elements of the study sample show significant differences. To do this we will use the one-factor ANOVA test and we will take into account the factor "country; 1 Spain, 2 Colombia, 3 Portugal". We will accept that the means are different and there are significant differences according to the university of origin if the significance value is less than 0.05 in the ANOVA analysis.

Table 4. Do you consider that you have the knowledge and skills to avoid plagiarism?

\begin{tabular}{|c|c|r|r|r|r|r|r|r|}
\hline & $\mathrm{N}$ & Average & $\begin{array}{c}\text { Standard } \\
\text { deviation }\end{array}$ & $\begin{array}{c}\text { Standard } \\
\text { error }\end{array}$ & \multicolumn{2}{c|}{$\begin{array}{c}\text { Confidence interval } \\
\text { for the 95\% mean }\end{array}$} & Minimum & Maximum \\
\hline & $\begin{array}{c}\text { Lower } \\
\text { limit }\end{array}$ & $\begin{array}{c}\text { Upper } \\
\text { limit }\end{array}$ & $\begin{array}{c}\text { Lower } \\
\text { limit }\end{array}$ & $\begin{array}{c}\text { Upper } \\
\text { limit }\end{array}$ & $\begin{array}{c}\text { Lower } \\
\text { limit }\end{array}$ & $\begin{array}{c}\text { Upper } \\
\text { limit }\end{array}$ & $\begin{array}{c}\text { Lower } \\
\text { limit }\end{array}$ & \multicolumn{2}{c|}{$\begin{array}{c}\text { Upper } \\
\text { limit }\end{array}$} \\
\hline 1,00 & 539 & $\mathbf{6 , 1 5}$ & 2,428 &, 105 & 5,94 & 6,36 & 0 & 10 \\
2,00 & 152 & $\mathbf{6 , 7 6}$ & 2,269 &, 184 & 6,40 & 7,13 & 0 & 10 \\
3,00 & 132 & $\mathbf{7 , 0 8}$ & 2,049 &, 178 & 6,73 & 7,44 & 1 & 10 \\
Total & 823 & $\mathbf{6 , 4 1}$ & 2,370 &, 083 & 6,25 & 6,58 & 0 & 10 \\
\hline
\end{tabular}

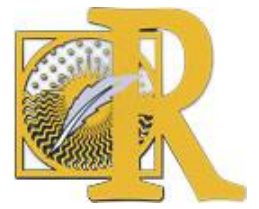


There is correlation when a clear trend is observed in which the mean is increasing, with the lowest value for Spain, followed by Colombia and the highest for Portugal. These differences are confirmed by Tukey's HSD in which the significances are less than 0.05 between Spain and Portugal, between Spain and Colombia, but not between Colombia and Portugal. We consider that this may be due in the case of Colombia to the fact that the ages of the students were higher in terms of the same group as can be seen in Table 1, and in the case of Portugal there were many postgraduate or master's degree students.

\section{Conclusions.}

The rapid and excessive increase of digitization processes in universities around the world brings with it both advantages and disadvantages associated with the implementation of technologies, both in security and digital skills (Gallego-Arrufat, et al., 2019). The increase is similar in both cases (advantages and disadvantages) encountering problematic situations or issues that we must address such as the proper and correct use from an ethical perspective, in particular, working to eliminate academic plagiarism (Mosteiro-García, 2021), to address among other issues, a booming market of online sales platforms on essays and academic papers (Comas-Forgas, 2021).

In the conclusions found in the present work, we will highlight the solutions to be taken into consideration, and according to the students, they are significantly grouped in three blocks: a first preventive and formative proposal, another punitive one and a third more lax one. There are not very significant differences by gender, with women reaching a lower level in the item of possible solutions.

In a comparative analysis, the responses of Portuguese students show a higher selfperception of themselves in relation to Spain and Colombia. These significant differences are also found according to the courses, starting with a higher self-perception in the second course, and increasing up to the postgraduate course, where it is higher than in the undergraduate courses. There are also significant differences in this self-perception by country, and this may be the reason why Colombia, followed by Portugal, with the highest number of graduate students, are the ones who consider that they have the most competences to face plagiarism.

Internet problems and especially those related to dishonest practices have students as the focus of attention in their study. Within this specialized literature, students are directly asked about their perception of what it means to plagiarize, and why they or their peers plagiarize (Cebrián-Robles, et al. 2016), finding patterns of behavior and internal and external justifications for plagiarizing (Cebrián-Robles, et al. 2020; Amiama-Espaillat, 2021). But rarely, as in the work of Muñoz-Cantero (2021), is he asked about the solutions that could be taken, as these issues seem more proper to institutional competences. (2020) addressed to presidents or secretaries of the social councils of Spanish universities; members of the Spanish Association of University Law (AEDUN) and university teachers with experience in academic management, where they were asked about the main fraudulent conducts, the level of seriousness and the sanctions that should be applied.

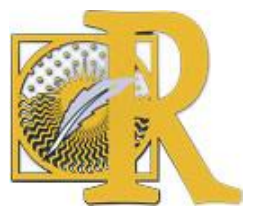

Fecha de recepción: 20-08-2021 Fecha de aceptación: 27-08-2021

Cebrián-Robles, V., Raposo-Rivas, M., Ruiz Rey, F. J. \& Cebrián De La Serna, M. (2021). Propuestas de los estudiantes para evitar el plagio académico

International Journal of Educational Research and Innovation (IJERI), 16, 223-235 ISSN: 2386-4303 DOI https://doi.org/10.46661/ijeri.6154 
However, in this study we have found interesting results when students are asked about these improvements directly. Undoubtedly, we do not exhaust all the possibilities that this change of focus and attention entails, but we certainly emphasize a line to be deepened in the future. As with all research, we need to continue investigating and improving some limiting aspects of the study, such as obtaining larger and more homogeneous samples, carrying out comparative studies in other contexts and educational levels, such as specialties and areas of knowledge, while analyzing these responses with the pandemic situation suffered recently with Covid19, where it is possible that the increase in digitization and the extreme situations such as pressure in which we have found ourselves, has led to certain situations, intentional or not, to practices that need to be corrected and attended to.

\section{References.}

- Adam, L., Anderson, V., \& Spronken-Smith, R. (2017). "It"s not fair': policy discourses and students' understandings of plagiarism in a New Zealand university. Higher Education, 74(1), 17-32. https://link.springer.com/article/10.1007/s10734-016-0025-9

- Amiama-Espaillat, C. (2021). El plagio en la Educación Superior dominicana: una oportunidad para desarrollar la escritura académica. Cuaderno de Pedagogía Universitaria, $18(35)$, 37-48. https://cuaderno.wh201.pucmm.edu.do/index.php/cuadernodepedagogia/article/view/411

- Amiri, F., \& Razmjoo, S. A. (2016). On Iranian EFL Undergraduate Students' Perceptions of Plagiarism. Journal of Academic Ethics, 14(2), 115-131. https://doi.org/10.1007/s10805015-9245-3

- Bretag, T. (Ed.). (2016). Handbook of Academic Integrity. Springer, Singapore. https://doi.org/10.1007/978-981-287-098-8

- Cabero-Almenara, J., Guillén-Gámez, F.F., Ruiz-Palmero, J. \& Palacios-Rodríguez, A., . (2021). Digital competence of higher education professor according to DigCompEdu. Statistical research methods with ANOVA between fields of knowledge in different age ranges. Education and Information Technologies. https://doi.org/10.1007/s10639-021$\underline{10476-5}$

- Muñoz-Cantero, J. M., Espiñeira- Bellón, E. M., \& Pérez-Crego, M. C. (2021). Medidas para combatir el plagio en los procesos de aprendizaje. Educación XX1, 24(2), 97-120. https://doi.org/10.5944/educxx1.28341

- Carretero, S., Vuorikari, V. And Punie, Y. (2018). DigComp 2.1: the digital competence framework for citizens with eight proficiency levels and examples of use. EU. https://op.europa.eu/s/pDOB

- Cebrián-Robles, V., Raposo-Rivas M \& Sarmiento-Campos J. (2016). ¿Ética o prácticas deshonestas? El plagio en las titulaciones de Educación. Revista Educación, 374, 161182. https://doi.org/10.4438/1988-592X-RE-2016-374-330

- Cebrián-Robles, V., Raposo-Rivas, M., Cebrián-de-la-Serna, M., \& Sarmiento-Campos, J. A. (2018). Percepción sobre el plagio académico de estudiantes universitarios españoles. Educación XX1, 21(2). https://doi.org/10.5944/educxx1.20062

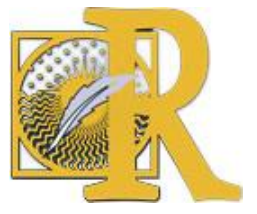

Fecha de recepción: 20-08-2021 Fecha de aceptación: 27-08-2021 
- Cebrián-Robles, V., Raposo-Rivas, M., \& Sarmiento-Campos, J. A. (2020). Study of the reasons for and measures to avoid plagiarism in young students of education. Profesorado, Revista de Currículum Y Formación Del Profesorado, 24(1), 50-74. https://doi.org/10.30827/profesorado.v24i1.8572

- Comas-Forgas, R., \& Sureda-Negre, J. (2010). Academic Plagiarism: Explanatory Factors from Students' Perspective. Journal of Academic Ethics, 8(3), 217-232. https://doi.org/10.1007/s10805-010-9121-0

- Comas-Forgas, R., Morey-López, M., \& Sureda-Negre, J. (2021). La publicidad en buscadores de las plataformas españolas de compraventa de trabajos académicos: análisis del tráfico, costes y palabras clave. Revista Española de Documentación Científica, 44(3), e298-e298. https://doi.org/10.3989/redc.2021.3.1767

- Ehrich, J., Howard, S. J., Mu, C., \& Bokosmaty, S. (2014). A comparison of Chinese and Australian university students' attitudes towards plagiarism. Studies in Higher Education, $O(0), 1-16$. https://doi.org/10.1080/03075079.2014.927850

- Gallego-Arrufat, M.-J., Torres-Hernández, N., \& Pessoa, T. (2019). Competencia de futuros docentes en el área de seguridad digital. Comunicar: Revista Científica de Comunicación y Educación, 27(61), 57-67. https://doi.org/10.3916/C61-2019-05

- Gasparyan, A. Y., Nurmashev, B., Seksenbayev, B., Trukhachev, V. I., Kostyukova, E. I., \& Kitas, G. D. (2017). Plagiarism in the Context of Education and Evolving Detection Strategies. Journal of Korean Medical Science, 32(8), 1220-1227. https://doi.org/10.3346/jkms.2017.32.8.1220

- Hernández, R., Fernández, C., y Baptista, P. (2014). Metodología de la investigación. México: McGrawHill

- Kaktinšs, L. (2018). Contract cheating advertisements: what they tell us about international students' attitudes to academic integrity. Ethics and Education, 13(2), 268-284. https://doi.org/10.1080/17449642.2017.1412178

- López-Puga, J. (2014). Análisis y reducción del plagio en la universidad. European Journal of Education and Psychology, 7(2), 131-140. https://doi.org/10.30552/ejep.v7i2.102

- Mosteiro-García. M. J., Espiñeira-Bellón, E. M., Porto-Castro, A. M. y Muñoz Cantero, J. M. (2021). El alumnado universitario ante la comisión de plagio por parte de sus compañeros/as. Revista de Investigación Educativa, 39(2), 391-409. https://doi.org/10.6018/rie.424381

- Redecker, C. (2017). Marco europeo para la competencia digital de los educadores. DigCompEdu. Comisión Europea. https://acortar.link/wU3qRH

- Sureda-Negre, J., Comas-Forgas, R., \& Oliver-Trobat, M.-F. (2015). Plagio académico entre alumnado de secundaria y bachillerato: Diferencias en cuanto al género y la procrastinación. Comunicar, 22(44), 103-111. https://doi.org/10.3916/C44-2015-11

- Sureda-Negre, J., Cerdá-Navarro, A., Calvo-Sastre, A. y Comas-Forgas, R., (2020). Las conductas fraudulentas del alumnado universitario español en las evaluaciones: valoración de su gravedad y propuestas de sanciones a partir de un panel de expertos. Revista de Investigación Educativa, vol. 38, núm. 1, pp. 201-219. http://dx.doi.org/10.6018/rie.358781

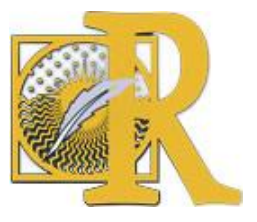

Fecha de recepción: 20-08-2021 Fecha de aceptación: 27-08-2021 
- Walker, C., \& White, M. (2014). Police, design, plan and manage: developing a framework for integrating staff roles and institutional policies into a plagiarism prevention strategy. Journal of Higher Education Policy and Management, 36(6), 674-687. https://doi.org/10.1080/1360080X.2014.957895

- Zrnec, A., \& Lavbič, D. (2017). Social network aided plagiarism detection. British Journal of Educational Technology: Journal of the Council for Educational Technology, 48(1), 113128. https://doi.org/10.1111/bjet.12345 